\title{
Monitoring Susceptibility of Whiteflies to Imidacloprid and Resistance Management for Nicotinoid Insecticides ${ }^{1}$
}

\author{
David J. Schuster, Sandra Thompson, and Roy F. Morris $\|^{2}$
}

Imidacloprid a nicotinoid insecticide that is applied at transplanting or within two to three weeks after transplanting to nearly $100 \%$ of the tomato acreage in Florida for control of the silverleaf whitefly (SLWF), Bemisia argentifolii Bellows \& Perring, and the geminiviruses it transmits, primarily tomato yellow leaf curl virus (TYLCV). A cut leaf petiole (CLP) method using cotton seedlings was used to develop the baseline level of susceptibility of whitefly adults from a laboratory colony to imidacloprid. The CLP method was easy and quick and was used to estimate the susceptibility of whitefly populations from three imidacloprid-treated tomato fields in the spring of 2000, nine in the spring of 2001, two in the fall of 2001, and 13 in the spring of 2002 using adults reared from field-collected nymphs. Standard probit analyses were used to estimate the $\mathrm{LC}_{50}$ values (the concentration estimated to kill $50 \%$ of the population) for the laboratory colony and for each field population. $\mathrm{LC}_{50}$ values of field populations ranged from about 2 to 35 times that of the highly susceptible laboratory colony. Values on the high side of the range were found at two sites in 2001 and two other sites in 2002. Two sites that had high values in 2001 did not have high values in 2002. In addition, SLWF populations were not reported by growers to be out of control at any of the sites, and in-field evaluations of imidacloprid efficacy in 2002 indicated expected levels of control of SLWF nymphs, even at the site that had an $\mathrm{LC}_{50}$ value 35 times the laboratory colony. Growers are encouraged to implement a resistance management program for nicotinoids by reducing overall whitefly populations and by rotating nicotinoids with insecticides of other chemistries.

\section{Introduction}

Nicotinoids (also known as neonicotinoids, chloronicotinyls, nitroquanidines and nitromethylenes) are a relatively new class of insecticides that are structured after naturally occurring nicotine compounds and act similarly on the central nervous system. They are translaminar

1. This document is ENY681, a publication of the Entomology and Nematology Sciences Department, Florida Cooperative Extension Service, Institute of Food and Agricultural Sciences, University of Florida. Publication Date: September 2003. Please visit the EDIS Website at http://edis.ifas.ufl.edu.

2. David J. Schuster, professor, Gulf Coast Research and Education Center, University of Florida/IFAS, Gulf Coast Research \& Education Center -

Bradenton; Sandra Thompson, technical assistant, Gulf Coast Research and Education Center- Bradenton, Cooperative Extension Service, Institute of Food and Agricultural Sciences, University of Florida, Gainesville, FL 32611. Roy F. Morris II, Technical Sales Specialist, Bayer CropScience, 2635

Ewell Rd., Lakeland, FL 33811

The use of trade names in this publication is solely for the purpose of providing specific information. UF/IFAS does not guarantee or warranty the products named, and references to them in this publication does not signify our approval to the exclusion of other products of suitable composition. All chemicals should be used in accordance with directions on the manufacturer's label. Use pesticides safely. Read and follow directions on the manufacturer's label.

The Institute of Food and Agricultural Sciences (IFAS) is an Equal Employment Opportunity - Affirmative Action Employer authorized to provide research, educational information and other services only to individuals and institutions that function without regard to race, creed, color, religion, age, disability, sex, sexual orientation, marital status, national origin, political opinions or affiliations. For information on obtaining other extension publications, contact your county Cooperative Extension Service office. Florida Cooperative Extension Service / Institute of Food and Agricultural Sciences / University of Florida / Larry R. Arrington, Interim Dean 
(readily absorbed into leaves) and highly systemic and, thus, may be applied as soil drenches or foliar sprays. Soil drenches have provided longest residual control of sucking insects including whiteflies. Imidacloprid (Bayer CropScience, Kansas City, MO) was the first nicotinoid insecticide available for use on tomatoes in Florida under a section 18 emergency use exemption in 1994, followed by full US EPA registration in 1995. Imidacloprid is formulated as Admire ${ }^{\circledR}$ for soil applications and Provado ${ }^{\circledR}$ for foliar applications. Thiamethoxam (Syngenta Crop Protection, Inc., Greensboro, NC) is another nicotinoid that was registered by the US EPA last year and is formulated as Platinum ${ }^{\circledR}$ for soil applications and Actara ${ }^{\circledR}$ for foliar applications. Recently, another nicotinoid, acetamiprid (Assail®, Aventis CropScience, Research Triangle Park, NC) was registered for whitefly control on tomato with foliar applications.

The silverleaf whitefly (SLWF), Bemisia argentifolii Bellows \& Perring (also known as biotype "B" of the sweetpotato whitefly, B. tabaci (Gennadius) ), is the key pest of tomatoes in south Florida causing losses by inducing the irregular ripening disorder of tomato fruit and by transmitting geminiviruses, the most damaging of which is tomato yellow leaf curl virus (TYLCV) (Schuster et al. 1996a,b). To avoid losses, particularly due to TYLCV, nearly $100 \%$ of the tomato transplant producers are applying Admire at least once seven to 10 days prior to transplanting. This application is made to help assure that the plants are protected against $B$. argentifolii for up to three weeks after transplanting. Another soil application of either Admire or Platinum is made, preferably in the transplant water when plants are transplanted. These applications provide whitefly and TYLCV control for three to 12 weeks, depending upon location and season (Schuster and Morris 2002). The heavy reliance upon the nicotinoids for whitefly management may lead to the development of resistance. A field strain of B. tabaci in Spain has been shown to be resistant to both imidacloprid and thiamethoxam (Elbert and Nauen 2000).

Information regarding the susceptibility of the SLWF in Florida to imidacloprid is needed because of the potential for the development of resistance in
Florida due to the over eight years of imidacloprid use on Florida tomatoes. The purpose of the present investigation was to assess and monitor the susceptibility of field populations to imidacloprid and to compare estimates of susceptibility with in-field efficacy of imidacloprid.

\section{Materials and Methods}

\section{Monitoring Susceptibility to Imidacloprid}

A cut leaf petiole (CLP) method was developed from modifications of methods reported previously (Cahill et al. 1996, Williams et al. 1996, Prabhaker et al. 1997). Cotton seedlings grown whitefly-free in the greenhouse were used at the two true leaf stage. The petioles of leaves of the cotton plants were cut and placed individually in vials containing solutions of different concentrations of imidacloprid. After 24 hrs, 10 SLWF adults were confined on each leaf with a clip cage for another $24 \mathrm{hrs}$ after which the resulting mortality was determined. Mortality was defined as any adult not capable of standing, walking or flying. The SLWF adults used had been reared on tomato in the laboratory for about 12 years without re-introduction of whiteflies from the field.

SLWF populations from 12 imidacloprid-treated tomato fields in 2001 and 13 fields in 2002 were compared with the laboratory colony for susceptibility to imidacloprid using the CLP method. Bioassays were conducted using adults reared from foliage infested with nymphs that had been collected from tomato fields that had been treated with imidacloprid at transplanting. Standard probit analyses was used to estimate the $\mathrm{LC}_{50}$ values for the laboratory colony and each field population (SAS Institute 1989). The relative susceptibility at the $50 \%$ mortality level $\left(\mathrm{RS}_{50}\right)$ was calculated by dividing the $\mathrm{LC}_{50}$ of the field population by that of the laboratory colony.

The progeny of adults that survived the bioassay from the Duette site in 2001 and the University of Florida's Southwest Florida Research \& Education Center (SWFREC) site in 2002 were reared in the lab on tomato without selection until sufficient adults were available to conduct another bioassay (about 4-6 generations based upon an average of 2 weeks for each generation) and then were bioassayed again. At 
the Immokalee1 and Ruskin1 sites in 2001, whitefly-free, greenhouse-grown tomato plants were placed on the field perimeters about 4 weeks after the crop had been destroyed. One week later, the plants were returned to the laboratory and held 4-5 weeks (about 2-3 generations) and the progeny bioassayed.

\section{Evaluating In-field Efficacy of Imidacloprid}

Ten experiments were conducted in the spring of 2002, one at the University of Florida's Gulf Coast Research \& Education Center (GCREC) and nine at commercial tomato farms (Table 1). Plots at all sites consisted of 2 rows and treatments were replicated three times (four times at Lorraine) in randomized complete block designs. Cultural details for each site are listed in Table 1. At all locations imidacloprid (Admire 2F) was applied at 16 ozs/acre and thiamethoxam (Platinum 2SC) was applied at 8 ozs/acre as a drench of 1.7 or 3.4 ozs of diluted insecticide per plant. Transplants at all locations were grown commercially and, with the exception of those set at GCREC and Homestead, were treated with imidacloprid in the plant house prior to delivery. Growers applied insecticides for armyworm control but not for whiteflies. The numbers of sessile whitefly nymphs were counted weekly on the terminal leaflet of the seventh or eighth leaf from the top of one stem from each of 10 plants of one row of each plot.

\section{Results and Discussion}

Over all three years, nearly $80 \%$ of the $\mathrm{RS}_{50}$ values of whiteflies collected from the imidacloprid-treated fields were 8 or less (Table 2). While values approaching 8 could indicate decreasing susceptibility of the whiteflies, such variability is not unexpected when comparing field-collected insects with susceptible, laboratory-reared insects. The laboratory colony used as a susceptible standard in this study has been in continuous culture since the late 1980's without the introduction of whiteflies collected from the field and, therefore, would be anticipated to be particularly susceptible to insecticides. In both 2001 and 2002 whiteflies from three populations had $\mathrm{RS}_{50}$ values of 10 or greater, which were sufficiently high to draw attention. This was particularly true of the SWFREC and Duette sites in 2002. Two of the sites that had high values in 2001 did not have high values in 2002. Because monitoring for susceptibility to imidacloprid has only been conducted on Florida tomatoes for three years, it is not known whether these six fields represent the higher points in the natural susceptibility range, a trend toward increasing tolerance or whether such events have occurred in the past and that observed increased tolerance disappeared or decreased between cropping seasons.

The $\mathrm{RS}_{50}$ values of the progeny of the whitefly populations from the Duette site in 2001 and the SWFREC site in 2002 decreased about $75-80 \%$ to acceptable levels after having been reared for 4-6 generations in the laboratory without selection (Table 3). Furthermore, the $\mathrm{RS}_{50}$ values for whitefly populations collected 4 wk after the end of the crops at the Immokalee1 and Ruskin 1 sites in 2001 were both about 2 compared to 15 and 5, respectively, during the season. Therefore, the high $\mathrm{RS}_{50}$ values in 2001 and 2002 may represent either the high end of natural levels of variability or may represent unstable shifts in reduced susceptibility, i.e. imidacloprid tolerance may increase at some sites during the season but dissipate or disappear during the off-season.

The densities of whitefly nymphs on the tomatoes at the SWFREC (Schuster et al. 2002) and Duette (Table 4) sites in 2002 were not especially high and none of the whitefly populations in sampled fields in 2001 and 2002, including the six with higher $\mathrm{RS}_{50}$ values, were out of control, thus suggesting variability in the populations or in the bioassay itself. Imidacloprid failed to provide significant reductions in the numbers of whitefly nymphs relative to the control at the Duette site. Even though the whitefly population increased late at this site, the same was true of other sites where significant reductions were observed. In addition, nymphal densities in 2002 were as high or higher at Boynton Beach, GCREC (field1) and Homestead as that at Duette, but those sites had $\mathrm{RS}_{50}$ values that were lower than that at Duette.

At the SWFREC site a row of collards was grown as a source of whiteflies for the experiment; however, it was observed from the distribution of whiteflies and TYLCV in the plots, that the whitefly 
population had migrated from outside SWFREC, presumably from nearby commercial fields at the end of harvest, and had not migrated from the collards. The experiment at the Duette site was initiated late in an experimental field that was separate from but surrounded by commercial fields. The experiment was still in progress when surrounding fields were being destroyed and whitefly adults could have migrated from these fields into the experiment. Thus, it is possible that the nymphal populations collected at the end of the experiments for estimating susceptibility to imidacloprid were not the same nymphal populations sampled for imidacloprid efficacy earlier in the experiments.

Despite the uncertainty of the meaning of elevated $\mathrm{RS}_{50}$ values from laboratory estimations of the field susceptibility of $B$. argentifolii to imidacloprid, the high level of some $\mathrm{RS}_{50}$ values at some sites, especially in 2002, should be of sufficient concern to growers to encourage them to redouble their efforts in implementing a nicotinoid resistance management program as outlined by Schuster and Thompson (2001).

\section{Nicotinoid Resistance Management Recommendations}

\section{Reduce overall whitefly populations and virus pressure by the following practices:}

- Plant whitefly-free transplants.

- Delay planting new crops as long as possible and destroy old crops immediately after harvest to create or lengthen a tomato-free period.

- Do not plant new crops near or adjacent to infested weeds or crops, abandoned fields awaiting destruction or areas with volunteer plants.

- Use UV-reflective (aluminum) plastic soil mulch to repel whiteflies.

- Control infested weeds on field edges if natural enemies are absent.

- Manage weeds within crops to minimize interference with spraying.
- Avoid u-picking or pin-hooking operations unless effective control measures are continued.

- If tomato is to be double cropped with another whitefly susceptible crop, control tomato regrowth or volunteer plants during the off season.

- Do not double crop tomato with tomato unless there is at least a 2-3 month break between crops.

\section{Reduce whitefly exposure to nicontinoid} insecticides by the following practices:

- Use a nicotinoid insecticide in transplants only once 7-10 days before transplanting, using other products in other chemical classes, including Fulfill ${ }^{\circledR}$, before this time.

- Apply a nicotinoid like Admire (16 ozs/acre) or Platinum (8ozs/acre) in the transplant water when transplanting and use products of other chemical classes (such as the insect growth regulators Knack ${ }^{\circledR}$ or Courier $\left.{ }^{\circledR}\right)$ as the control with the nicotinoid diminishes.

- Never follow an application (soil or foliar) of a nicotinoid with another application (soil or foliar) of the same or different nicotinoid on the same crop or in the same field within the same cropping season (i.e. do not treat a double crop with a nicotinoid if the main crop had been treated previously and if the double crop is planted without a 2-3 month break from the main crop).

- Save applications of nicotinoids for crops threatened by whitefly-transmitted plant viruses or whitefly-inflicted disorders (i.e. tomato, beans or squash) and use chemicals of other classes for whitefly control on other crops.

\section{References Cited}

Cahill, M., K. Gorman, S. Day, I. Denholm, A. Elbert and R. Nauen. 1996. Baseline Determination and Detection of Resistance to Imidacloprid in Bemisia tabaci (Homoptera: Aleyrodidae). Bull. Entomol. Res. 86:343-349. 
Elbert, A. and R. Nauen. 2000. Resistance in Bemisia tabaci (Homoptera: Aleyrodidae) to Insecticides in Southern Spain with Special Reference to Neonicotinoids. Pest Management Sci. 56:60-64.

Prabhaker, N., N. C. Toscano, S. J. Castle and T. J. Henneberry. 1997. Selection for Imidacloprid Resistance in Silverleaf Whiteflies from the Imperial Valley and Development of a Hydroponic Bioassay for Resistance Monitoring. Pestic. Sci. 51:419-428.

SAS Instititute Inc. 1989. SAS/STAT Users Guide, Version 6, Fourth Edition, Bol. E, SAS Institute Inc., Cary, NC.

Schuster, D. J. and R. F. Morris II. 2002. Comparison of Nicotinoid Insecticides for Control of the Silverleaf Whitefly, Bemisia argentifolii Bellows \& Perring, and the Leafminer, Liriomyza trifolii, on Tomato. Proc. Fla. State Hort. Soc. 115 (accepted).

Schuster, D. J. and S. Thompson. 2001. Monitoring Susceptibility of the Silverleaf Whitefly to Imidacloprid, pp. 16-18. In P. Gilreath and C. S. Vavrina [eds.], 2001 Florida Tomato Institute Proceedings. Univ. of Fla., IFAS, PRO 518.

Schuster, D. J., J. E. Funderburk and P. A. Stansly. 1996a. IPM in Tomatoes, pp. 367-411. In D. Rosen, F. D. Bennett and J. L. Capinera [eds.], Pest management in the Subtropics, Integrated Pest Management - a Florida Perspective. Intercept Ltd., Andover, Hants, United Kingdom.

Schuster, D. J., P. A. Stansly and J. E. Polston. 1996b. Expressions of Plant Damage by Bemisia, pp. 153-165. In D. Gerling and R. T. Mayer [eds.], Bemisia 1995: Taxonomy, Damage, Control and Management. Intercept Ltd., Andover, Hants, United Kingdom.

Schuster, D. J., S. Thompson, P. A. Stansly and J. Conner. 2002. Update on Insecticides for Whitefly and Leafminer Control, pp. 51-60. In P. Gilreath and C. S. Vavrina [eds.], 2001 Florida Tomato Institute Proceedings. Univ. of Fla., IFAS, PRO 519.

Williams, L. III, T. J. Dennehy and J. C. Palumbo. 1996. Whitefly Control in Arizona:
Development of a Resistance Management Program for Imidacloprid. Proc. Beltwide Cotton Conf. 752-755. 
Table 1. Cultural details of experiments comparing the efficacy of soil applications of nicotinoid insecticides for whitefly and leafminer control on tomato, Spring 2002.

\begin{tabular}{|c|c|c|c|c|c|c|c|c|}
\hline \multirow[b]{2}{*}{ Site } & \multirow[b]{2}{*}{ Cultivar } & \multirow{2}{*}{$\begin{array}{l}\text { Irrigation } \\
\text { method }\end{array}$} & \multirow{2}{*}{$\begin{array}{c}\text { Planting } \\
\text { date }\end{array}$} & \multirow{2}{*}{$\begin{array}{c}\text { Treatment } \\
\text { date }\end{array}$} & \multicolumn{2}{|c|}{ Spacing } & \multirow{2}{*}{$\begin{array}{c}\text { No. } \\
\text { plant/row }\end{array}$} & \multirow{2}{*}{$\begin{array}{c}\text { No. } \\
\text { plants/acre }\end{array}$} \\
\hline & & & & & $\begin{array}{r}\text { Row } \\
\text { (ft.) }\end{array}$ & $\begin{array}{c}\text { Plant } \\
\text { (in.) }\end{array}$ & & \\
\hline \multicolumn{9}{|c|}{ Collier County } \\
\hline $\begin{array}{l}\text { Immokalee } \\
1\end{array}$ & Florida 47 & Seep & $23 \mathrm{Dec}$ & 3 Jan & 6 & 20 & 15 & 4356 \\
\hline $\begin{array}{l}\text { Immokalee } \\
2\end{array}$ & Florida 47 & Drip & $27 \mathrm{Dec}$ & 15 Jan & 6 & 28 & 15 & 3111 \\
\hline \multicolumn{9}{|c|}{ Dade County } \\
\hline Homestead & Florida 47 & Drip & $12 \mathrm{Mar}$ & 19 Mar & 6 & 20 & 15 & 4356 \\
\hline \multicolumn{9}{|c|}{ Hillsborough County } \\
\hline Ruskin 1 & Florida 47 & Seep & $21 \mathrm{Jan}$ & 21 Jan & 6 & 30 & 12 & 2904 \\
\hline Ruskin 2 & \multicolumn{7}{|c|}{ Manatee County } & 4356 \\
\hline Lorraine & Asgrow 91 & Drip & $1 \mathrm{Mar}$ & 1 Mar & 6 & 22 & 15 & 3960 \\
\hline Duette & Florida 47 & Drip & $7 \mathrm{Mar}$ & 7 Mar & 6 & 24 & 15 & 3630 \\
\hline Bradenton & Mt. Fresh & Seep & $12 \mathrm{Mar}$ & $12 \mathrm{Mar}$ & 5 & 18 & 12 & 5808 \\
\hline Ft. Hamer & Florida 47 & Seep & $15 \mathrm{Feb}$ & $15 \mathrm{feb}$ & 7 & 28 & 12 & 2677 \\
\hline \multicolumn{9}{|c|}{ Palm Beach County } \\
\hline $\begin{array}{l}\text { Boynton } \\
\text { Beach }\end{array}$ & $\begin{array}{l}\text { Undisclosed } \\
\text { grape type }\end{array}$ & Drip & 25 Jan & 4 Feb & 6 & 24 & 15 & 3630 \\
\hline
\end{tabular}

Table 2. Relative susceptibility $\left(\mathrm{RS}_{50}{ }^{1}\right.$ ) of silverleaf whitefly adults to imidacloprid in a laboratory bioassay. Adults were reared from nymph-infested foliage collected from tomato fields treated with imidacloprid at transplanting.

\begin{tabular}{|lrr|}
\hline \hline County/Site & 2001 & 2002 \\
\hline Collier/Immokalee 1, Field 1 & 8.0 & 7.3 \\
Collier/Immokalee 1, Field 2 & 14.6 & 3.9 \\
Collier/Immokalee 2 & 5.1 & --- \\
Collier/Immokalee 3 & ---- & 5.6 \\
Collier/Immokalee 4 & ---- & 2.9 \\
Collier/SWFREC & ---- & 21.9 \\
Dade/Homestead & ---- & 7.3 \\
Hendry/Devil's Garden & 3.1 & --- \\
Hillsborough/Riverview & 4.5 & ---- \\
Hillsborough/Ruskin 1 & 4.6 & ---- \\
Hillsborough/Ruskin 2 & ---- & 3.4 \\
Manatee/Duette, Field 1 (May) & 10.6 & ---- \\
Manatee/Duette, Field 1 (June) & 8.0 & ---- \\
Manatee/Duette, Field 2 & ---- & 35.2 \\
Manatee/Ft. Hamer & 13.1 & 5.7 \\
Manatee/GCREC, Field 1 & 2.6 & 5.9 \\
Manatee/GCREC, Field 2 & 1.0 & ---- \\
Manatee/GCREC, Field 3 & ---- & 14.8 \\
\hline \hline
\end{tabular}


Table 2. Relative susceptibility $\left(\mathrm{RS}_{50}{ }^{1}\right)$ of silverleaf whitefly adults to imidacloprid in a laboratory bioassay. Adults were reared from nymph-infested foliage collected from tomato fields treated with imidacloprid at transplanting.

\begin{tabular}{lrr|}
\hline \hline County/Site & 2001 & 2002 \\
\hline Manatee/Myakka City & 4.7 & --- \\
Manateee/Lorraine & --- & 2.6 \\
Palm Beach Boynton Beach & $-C_{50}$ of the indicated population to the LC $_{50}$ \\
\hline${ }^{1}$ Ratio of the LC & \\
teh laboratory colony. Increasing values greater than one \\
indicate decreasing susceptibility to imidacloprid relative to \\
the laboratory colony. \\
\end{tabular}

Table 3. Changes in relative imidacloprid susceptibility $\left(\mathrm{RS}_{50}{ }^{1}\right)$ of silverleaf whitefly adults evaluated two to four generations following collection in the field 2001.

\begin{tabular}{|c|c|c|c|c|}
\hline \multirow[b]{2}{*}{ Site } & \multicolumn{2}{|c|}{ Date } & \multirow{2}{*}{$\begin{array}{c}\text { Estimated no. } \\
\text { generations } \\
\text { in lab }\end{array}$} & \multirow[b]{2}{*}{$\mathrm{RS}_{50}{ }^{1}$} \\
\hline & Collected & Evaluated & & \\
\hline \multicolumn{5}{|c|}{2001} \\
\hline Immokalee 1 & 8 May & 18 May & 1 & 14.6 \\
\hline Immokalee 1 & 6-13 July ${ }^{2}$ & 18 Aug & $2-3$ & 2.2 \\
\hline Ruskin 1 & 13 June & 21 June & 1 & 4.6 \\
\hline Ruskin 1 & 19-26 July² & 25 Aug & 2 & 1.5 \\
\hline Duette & 13 June & 21 June & 1 & 8.0 \\
\hline Duette & 13 June & $16 \mathrm{Aug}^{3}$ & 4 & 1.5 \\
\hline \multicolumn{5}{|c|}{2002} \\
\hline SWFREC & 21 May & 31 May & 1 & 21.7 \\
\hline SWFREC & 21 May & $28 \mathrm{Aug}^{3}$ & $5-6$ & 5.8 \\
\hline \multicolumn{5}{|c|}{$\begin{array}{l}{ }^{2} \text { Collected as adults on whitefly-free tomato plants placed in the field about } 4 \text { wk after crop } \\
\text { destruction. }\end{array}$} \\
\hline \multicolumn{5}{|c|}{${ }^{3}$ Survivors of the original bioassay were reared on tomato without selection in the lab. } \\
\hline
\end{tabular}




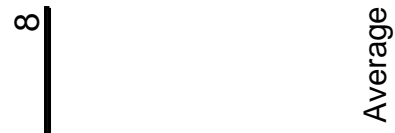

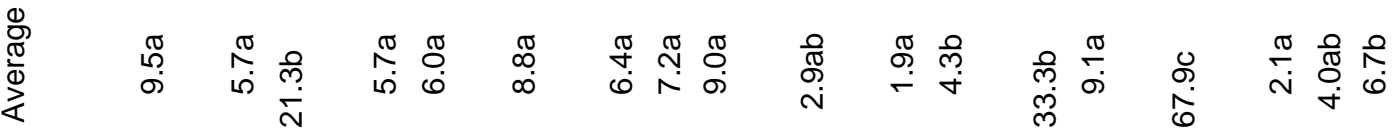

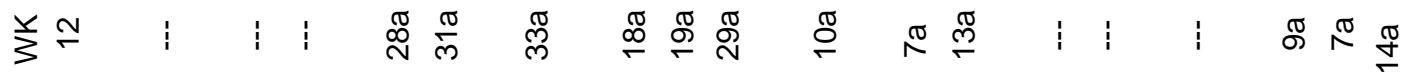

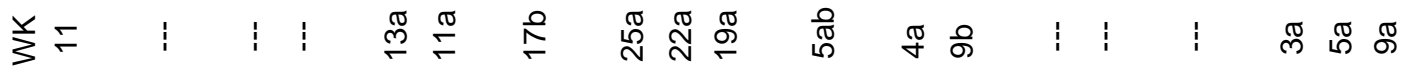

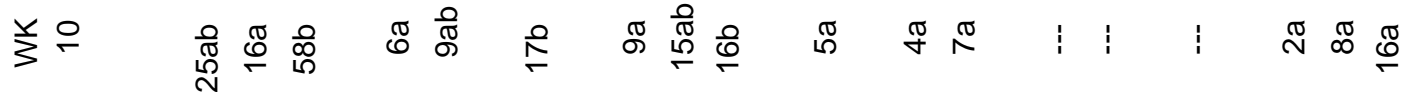

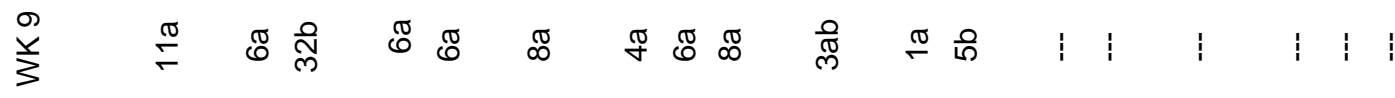

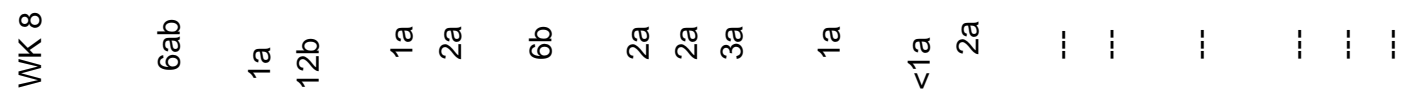

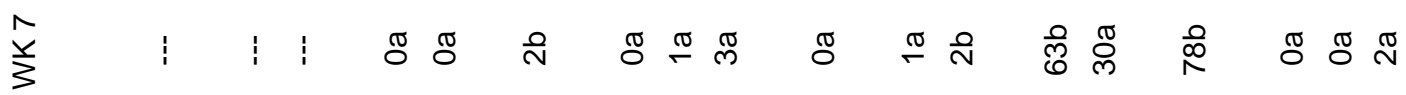

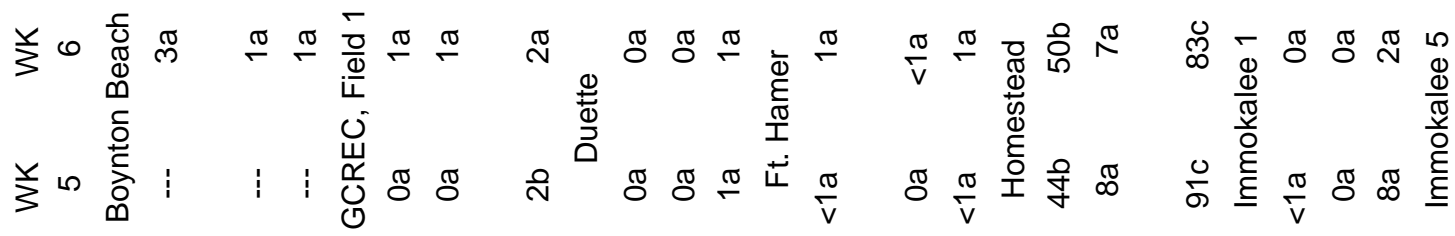

艾 $\quad$ ก

产m : :

$\stackrel{\sim}{\stackrel{r}{3}}$

$\overline{\check{Y}}$

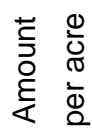

$\begin{array}{lllll}N & \infty & & N & N \\ N & N & & N & 0 \\ \infty & 0 & & \infty & 0\end{array}$

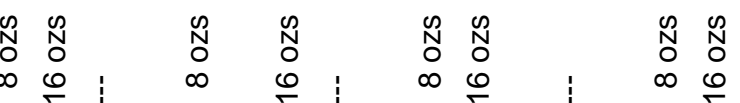




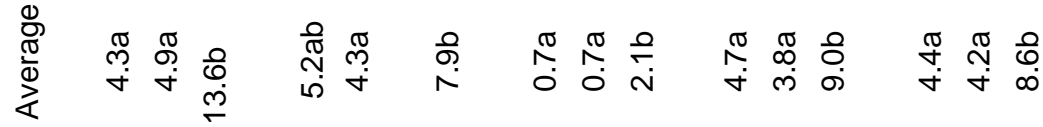

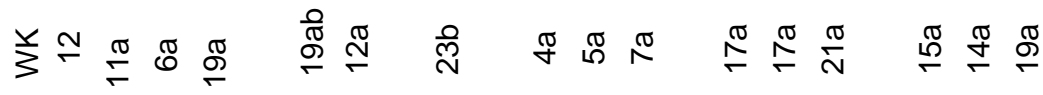

芝

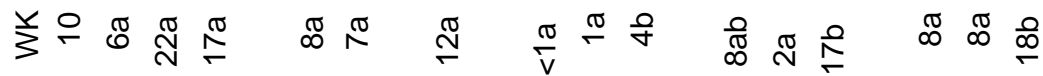

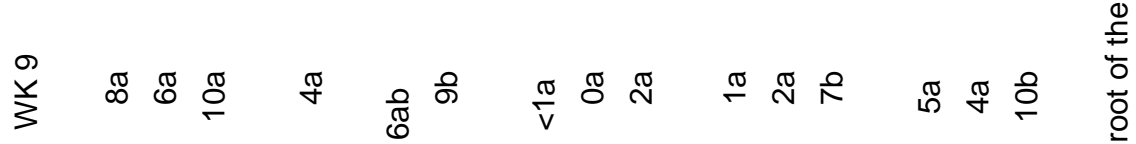

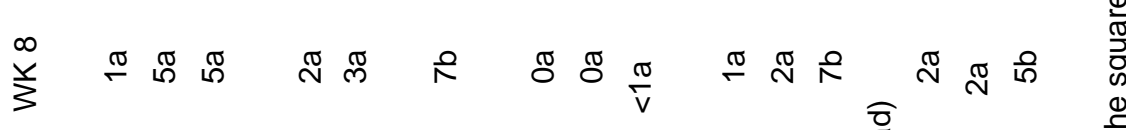

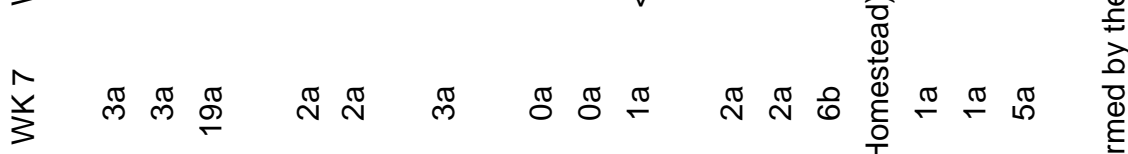

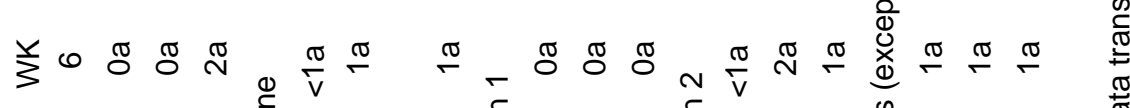

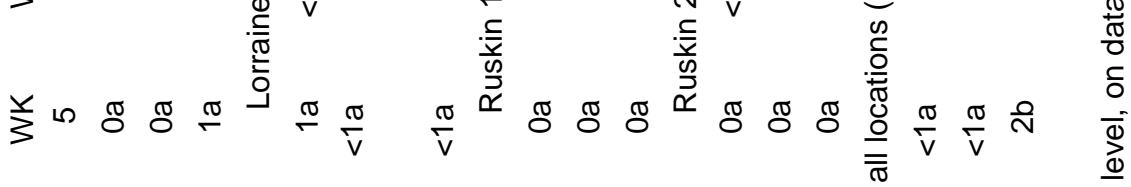

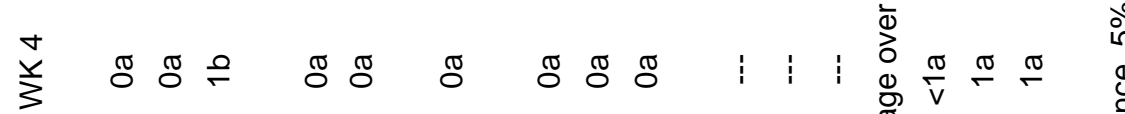

产m

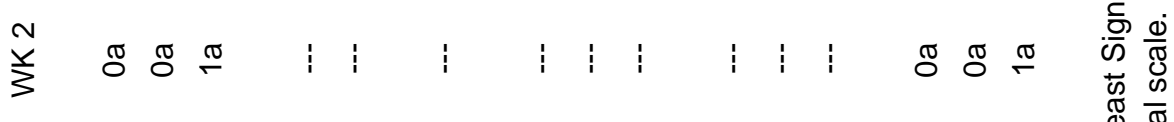

$\bar{\Sigma}$

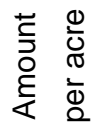

$\begin{array}{lllll}N & N & N & N \\ N & N & & N & N \\ \infty & 0 & \infty & \infty & 0\end{array}$

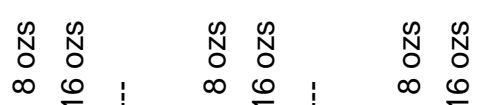

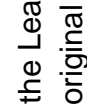

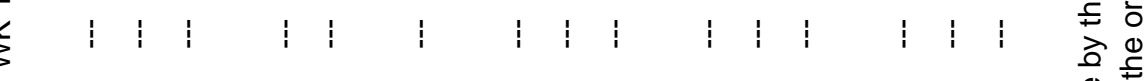

क

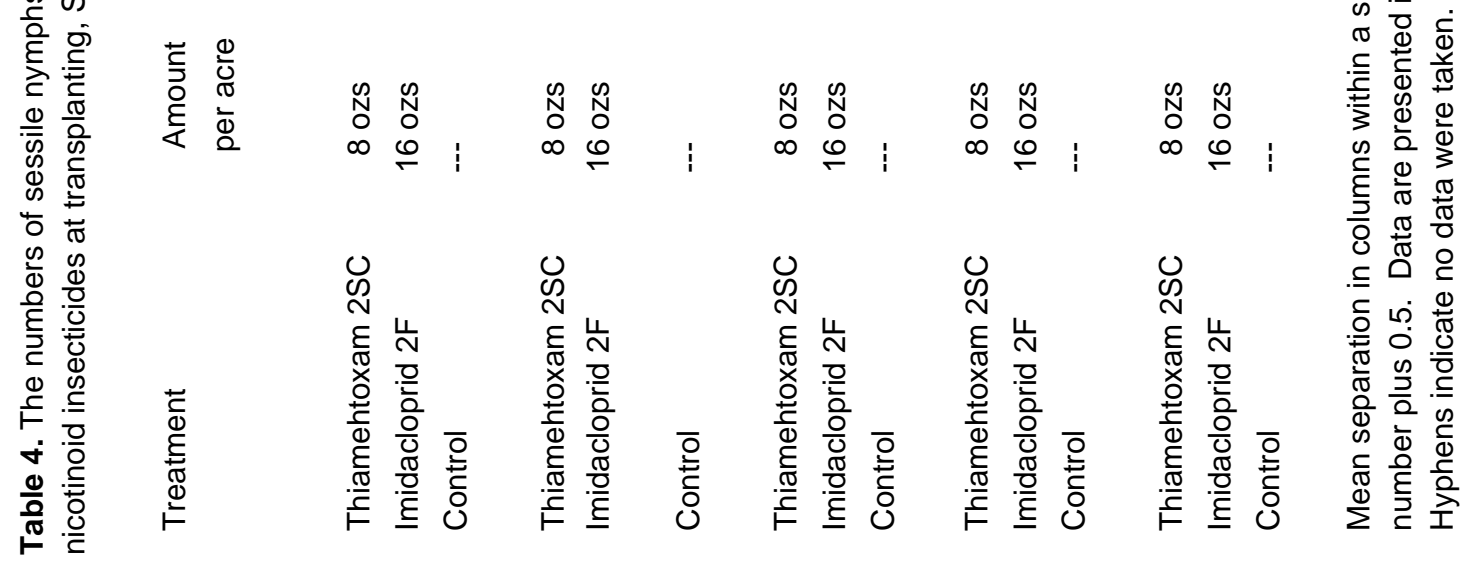

